\title{
Desulfovibrio alkalitolerans sp. nov., a novel alkalitolerant, sulphate-reducing bacterium isolated from district heating water
}

\author{
Lone Abildgaard, Marie Bank Nielsen, Kasper Urup Kjeldsen \\ and Kjeld Ingvorsen \\ Department of Microbiology, Institute of Biological Sciences, University of Aarhus, Denmark
}

Correspondence

Kjeld Ingvorsen

kjeld.ingvorsen@biology.au.dk
Physico-chemical interactions between a metallic material and its environment can lead to corrosion. Such deterioration of metal surfaces can be accelerated by microbial activity, termed microbially influenced corrosion (MIC) (Hamilton, 1998). The micro-organisms that have been most extensively studied in relation to MIC are sulphate-reducing bacteria (SRB) (Hamilton, 1998). MIC caused by SRB has been attributed mainly to the production of corrosive hydrogen sulphide and cathode depolarization, enhanced by their consumption of chemically produced hydrogen (Hamilton, 1985, 2003). Among SRB, Desulfovibrio species efficiently utilize hydrogen (Widdel \& Bak, 1992; Peck, 1993). Consequently, MIC is commonly attributed to members of this genus (Rao et al., 2000; Pak et al., 2003; Pankhania, 1988). Recently, two novel Desulfovibrio strains were isolated that reportedly were capable of using metallic iron as the sole electron donor for the dissimilatory reduction of sulphate, in a process in which hydrogen does not act as an intermediate electron carrier (Dinh et al., 2004). The isolation of these two strains thus suggested a novel and more direct mechanism of MIC than that involving consumption of

Abbreviations: MIC, microbially influenced corrosion; SRB, sulphatereducing bacteria.

The GenBank/EMBL/DDBJ accession numbers for the 16S rRNA, dsrAB and apsA gene sequences of strain $\mathrm{RT}^{\top}$ are AY649785, AY864856 and AY744465, respectively.

A transmission electron photomicrograph of a cell of strain $\mathrm{RT}^{\top}$ grown on lactate with sulphate as the electron acceptor and consensus trees showing the phylogenetic affiliations of the DsrAB and ApsA amino acid sequences of strain $\mathrm{RT}^{\top}$ are available as supplementary material in IJSEM Online. cathodic hydrogen. In many Danish cities, district heating systems work by circulating hot water to and from a heating plant to houses in a closed piping network. In order to prevent both chemical corrosion and growth of microorganisms, the circulating water is regularly treated by deaeration, reverse osmosis and sodium hydroxide amendment, thereby maintaining anoxic, nutrient-poor and alkaline conditions in the system (Goeres et al., 1998). Despite these measures, total bacterial counts of around $10^{5}$ cells per $\mathrm{ml}$ district heating water have been reported in waters of various Danish district heating systems, some of which have been exposed to MIC (Kjellerup et al., 2003). The presence of SRB has been demonstrated in several Danish district heating systems; however, their identity and their physiology were not investigated (Kjellerup et al., 2003, 2005). Although SRB thrive in a broad range of environments, only a few species, representing the genera Desulfonatronovibrio and Desulfonatronum, are obligately alkaliphilic. Some of these bacteria are able to grow at $\mathrm{pH}$ values $>10$ and not below pH 7·0 (Zhilina et al., 1997, 2005; Pikuta et al., 1998, 2003). In addition, a moderately alkaliphilic species with a growth range between $\mathrm{pH} 8.0$ and 9.2 is known within the genus Desulfotomaculum (Pikuta et al., 2000). However, to date alkalitolerant members of the environmentally widely distributed genus Desulfovibrio have not been described. This paper describes the first reported characterization of an alkalitolerant SRB (strain RT2 ${ }^{\mathrm{T}}$ ), affiliated to the genus Desulfovibrio.

Strain $\mathrm{RT} 2^{\mathrm{T}}$ was isolated from biofilms growing in the alkaline waters of a Danish district heating system where corrosion of the pipes had occurred. The biofilm samples 
were harvested from mild steel coupons $(6 \cdot 0 \times 2 \cdot 4 \mathrm{~cm})$, which had been incubated for 4 months in a rotortorque reactor connected to the return line of the district heating system in Skanderborg (Jutland, Denmark). Typical characteristics of the return-line water were as follows: conductivity $\left(<25 \mu \mathrm{S} \mathrm{cm}^{-1}\right)$, sulphate $(<20 \mu \mathrm{M})$, chloride ions $(<750 \mu \mathrm{M})$, total inorganic nitrogen $(<300 \mu \mathrm{M})$ and $\mathrm{pH}$ $(9 \cdot 5-10)$. The temperature of the anoxic return-line water was approximately $40{ }^{\circ} \mathrm{C}$. Most of the biofilm was aseptically scraped off the steel coupons for use in other investigations (K. U. Kjeldsen, B. V. Kjellerup, K. Egli, B. Frølund, P. H. Nielsen and K. Ingvorsen, unpublished data) and the coupons were subsequently transferred to modified anoxic Widdel and Bak medium (Widdel \& Bak, 1992) for enrichment of SRB. The modified medium (CM medium) comprised [g (1 Milli-Q water) ${ }^{-1}$ ]: $\mathrm{NaCl}, 1 \cdot 0 ; \mathrm{MgCl}_{2} \cdot 6 \mathrm{H}_{2} \mathrm{O}, 0 \cdot 1$; $\mathrm{CaCl}_{2} .2 \mathrm{H}_{2} \mathrm{O}, 0 \cdot 05 ; \mathrm{Na}_{2} \mathrm{SO}_{4}, 2 \cdot 0$ (4.0 after initial enrichments); $\mathrm{NH}_{4} \mathrm{Cl}, 0 \cdot 25 ; \mathrm{KH}_{2} \mathrm{PO}_{4}, 0 \cdot 1 ; \mathrm{KCl}, 0 \cdot 5$; yeast extract (IDG) 0.5 ; CAPSO [3-(cyclohexylamino)-2-hydroxy-1propansulphonic acid, $\left.\mathrm{p} K_{\mathrm{a}}=9 \cdot 4,37^{\circ} \mathrm{C}\right], 11 \cdot 85$. In addition, $1 \mathrm{ml}$ trace mineral solution $\mathrm{l}^{-1}$ (Ingvorsen \& Jørgensen, 1984) and $1 \mathrm{ml}$ selenite-tungstate solution $\mathrm{l}^{-1}$ (Widdel \& Bak, 1992) were added. The final $\mathrm{pH}$ of the medium was adjusted to $9 \cdot 0$ (after sterilization by autoclaving) using sterile $\mathrm{NaOH}$. For the initial enrichment of SRB, a mixture of glucose, pyruvate, lactate, propionate and acetate $(2 \mathrm{mM}$ final concentration of each added substrate) was added to the CM medium from sterile anoxic stock solutions. The enrichments were incubated at $40{ }^{\circ} \mathrm{C}$ in the dark. After approximately 1 month of incubation of the mild steel coupons in CM medium, turbidity and sulphide production were observed in some enrichment cultures. Strain RT2 ${ }^{\mathrm{T}}$ was isolated from one of these enrichments by repeated (three times) application of the roll-tube dilution technique (Hungate, 1976) using CM medium supplemented with hydrogen $(0.6 \mathrm{~atm}$. in headspace), acetate $(20 \mathrm{mM})$, thiosulphate $(20 \mathrm{mM})$ and agar $(2 \%, \mathrm{w} / \mathrm{v})$. The purity of the culture was checked using phase-contrast microscopy at regular intervals. In addition, the purity of the isolate was tested by microscopy after incubation in sulphate-free CM medium ( $\mathrm{pH} 7 \cdot 5$ or $9 \cdot 0)$ containing yeast extract $(0 \cdot 15 \%$, $\mathrm{w} / \mathrm{v})$, glucose $(10 \mathrm{mM})$ and pyruvate $(20 \mathrm{mM})$. Aerobic growth was tested on nutrient broth (Scharlau Chemie) agar plates. Colonies of strain RT2 ${ }^{\mathrm{T}}$ were disc-shaped and black, with a diameter of approximately $1 \mathrm{~mm}$. In sulphatecontaining CM medium, the cells were rod-shaped and slightly curved $(1 \cdot 4-1 \cdot 9 \mu \mathrm{m}$ long and $0 \cdot 5-0 \cdot 8 \mu \mathrm{m}$ wide), whereas thiosulphate-grown cells appeared to be slightly wider. Dividing cells often occurred in chains. Spores were never observed. Transmission electron micrographs were obtained as described previously (Abildgaard et al., 2004). These demonstrated the presence of a single polar flagellum, which was up to 3.5 times the length of the cells of strain $\mathrm{RT}^{\mathrm{T}}{ }^{\mathrm{T}}$ (see Supplementary Fig. S1 in IJSEM Online).

Growth tests were performed in CM medium adjusted to pH $9 \cdot 0$ (unless otherwise noted) in $16 \times 125 \mathrm{~mm}$ Hungate anaerobic culture tubes (Bellco Glass) with $3 \mathrm{ml}$ gas phase (nitrogen). Incubations were routinely carried out at $40{ }^{\circ} \mathrm{C}$ in the dark. Growth was evaluated microscopically, by measuring the $\mathrm{OD}_{600}$ directly in the tubes using a Novaspec II spectrophotometer (Pharmacia Biotech) fitted with a tube adaptor, and by following the production of sulphide using the method of Cline (1969). All substrate utilization experiments were performed in duplicate. Cultures were transferred to fresh medium at least three times to confirm the results. Incubations were maintained for at least 3 months and checked for growth on a regular basis. Electron acceptor utilization tests were done in sulphate-free $\mathrm{CM}$ medium supplemented with lactate $(20 \mathrm{mM})$. The ability to utilize metallic iron as a growth substrate was tested in modified $\mathrm{CM}$ medium ( $\mathrm{pH} 9 \cdot 0$ ) containing a low concentration of sulphate $(4 \mathrm{mM})$, sterile mild steel coupons, yeast extract $(0.05 \%, \mathrm{w} / \mathrm{v})$ and acetate ( $1 \mathrm{mM}$ final concentration). Separate control incubations with and without yeast extract, acetate and mild steel coupons were also performed. In addition, the sulphate-reducing activity in the various types of incubation was measured by using the sensitive ${ }^{35} \mathrm{~S}$-tracer technique with the single-step chromium reduction method to recover reduced sulphur species (Fossing \& Jørgensen, 1989). Tracer incubations were initiated by injecting carrierfree ${ }^{35} \mathrm{SO}_{4}^{2-}$ (Isotope Laboratory, Risø, Denmark) at a final activity of $26 \mathrm{kBq}$ ( $\mathrm{ml}$ culture) ${ }^{-1}$ and then incubated at $40{ }^{\circ} \mathrm{C}$ for 27 days. Subsamples $(1.0 \mathrm{ml})$ from the tracer incubations were removed with a syringe and mixed with a zinc acetate solution $(20 \%, \mathrm{w} / \mathrm{v})$ to stop the biological activity and preserve the ${ }^{35} \mathrm{~S}$-sulphides produced. The ${ }^{35} \mathrm{~S}$ activity was determined by liquid scintillation counting (Packard TRI-CARB 2900TR). Temperature, $\mathrm{pH}$ and $\mathrm{NaCl}$ experiments were carried out using lactate $(20 \mathrm{mM})$ as electron donor and sulphate as electron acceptor. Temperature experiments were performed simultaneously (in duplicate) at 21 temperatures ranging from $7 \cdot 3$ to $54 \cdot 3^{\circ} \mathrm{C}$ using a temperature gradient block (Elsgaard et al., 1994). The $\mathrm{pH}$ tolerance was tested in triplicate at $\mathrm{pH}$ values ranging from $6 \cdot 4$ to $10 \cdot 8$. The $\mathrm{pH}$ of the medium was measured once a day throughout these experiments. In media adjusted to initial $\mathrm{pH}$ values below $7 \cdot 5$, the $\mathrm{pH}$ slowly increased during incubation and therefore the growth rates in these incubations were estimated from the initial part of the growth curves. The $\mathrm{pH}$ tolerance was further tested in duplicate incubations at six $\mathrm{pH}$ values ranging from $9 \cdot 7$ to $10 \cdot 3$. The $\mathrm{pH}$ of the medium was measured twice a day and adjusted if necessary during these incubations. Growing cultures were retransferred to fresh medium of the same $\mathrm{pH}$ to confirm the results. At $\mathrm{pH}$ values above $9 \cdot 8$, some precipitation of medium components occurred. However, it was still possible to distinguish between cell growth and precipitation by reference to a substrate-free control and by measuring sulphide concentrations. The salt requirement for growth was tested in duplicate at $12 \mathrm{NaCl}$ concentrations ranging from approximately $0 \cdot 8$ to $10 \cdot 0 \mathrm{~g} \mathrm{l}^{-1}$. Strain $\mathrm{RT}^{\mathrm{T}}$ grew between 16 and $47^{\circ} \mathrm{C}$ (optimum growth temperature, $43^{\circ} \mathrm{C}$; doubling time, $\sim 4 \mathrm{~h}$ ) using lactate and sulphate $(20 \mathrm{mM}$ each) in media at a $\mathrm{pH}$ of $9 \cdot 0$ and $0 \cdot 13 \%(\mathrm{w} / \mathrm{v})$ $\mathrm{NaCl}$. The strain was able to grow at $\mathrm{pH}$ values ranging from 
$6 \cdot 9$ to $9 \cdot 9$, with an optimum $\mathrm{pH}$ for growth of $9 \cdot 0-9 \cdot 4$ (Fig. 1). The strain grew at $\mathrm{NaCl}$ concentrations ranging from 0.085 to $0.7 \%(\mathrm{w} / \mathrm{v})$. With sulphate as electron acceptor, strain $\mathrm{RT} 2^{\mathrm{T}}$ grew with lactate $(10 \mathrm{mM})$, pyruvate $(10 \mathrm{mM})$, formate $(15 \mathrm{mM})$ and hydrogen/acetate $(5 \mathrm{mM})$. No growth in the presence of sulphate was observed with propionate $(10 \mathrm{mM})$, fumarate $(10 \mathrm{mM})$, malate $(10 \mathrm{mM})$, acetate $(10 \mathrm{mM})$, benzoate $(10 \mathrm{mM})$, butyrate $(5 \mathrm{mM})$, citrate $(10 \mathrm{mM})$, succinate $(10 \mathrm{mM})$, oxamate $(10 \mathrm{mM})$, fructose $(5 \mathrm{mM})$, galactose $(5 \mathrm{mM})$, glucose $(5 \mathrm{mM})$, lactose $(5 \mathrm{mM})$, maltose $(5 \mathrm{mM})$, raffinose $(5 \mathrm{mM})$, sucrose $(5 \mathrm{mM})$, xylose $(5 \mathrm{mM})$, glycerol $(10 \mathrm{mM})$, choline $(5 \mathrm{mM})$, ethanol $(10 \mathrm{mM})$, methanol $(10 \mathrm{mM})$, butanol $(10 \mathrm{mM})$ or propanol $(10 \mathrm{mM})$. Yeast extract was required for growth. When strain $\mathrm{RT}^{\mathrm{T}}$ was incubated in medium containing yeast extract $(0.05 \%, \mathrm{w} / \mathrm{v})$, acetate and mild steel coupons, consistent blackening of the medium occurred during eight consecutive transfers. However, microscopy revealed no more than a few free-living cells in these subcultures and only extremely low sulphate reduction rates $\left(<1 \mu \mathrm{M} \mathrm{day}{ }^{-1}\right)$ were detected with the ${ }^{35} S$ radiotracer experiments. Thus, the mild steel coupons (i.e. $\mathrm{Fe}^{0}$ ) probably did not serve as an efficient electron donor for strain $\mathrm{RT}^{\mathrm{T}}$. In addition to sulphate, thiosulphate $(10 \mathrm{mM})$ and sulphite $(5 \mathrm{mM})$ could be utilized as electron acceptors using lactate as electron donor. Nitrate (2 $\mathrm{mM})$, elemental sulphur (approx. $20 \mathrm{~g} \mathrm{l}^{-1}$ ) and ferric iron [10 $\mathrm{mM}$; added from a $\mathrm{FeCl}_{3}$ solution of neutral $\mathrm{pH}$ prepared according to Lovley (2000)] did not support growth of strain RT2 ${ }^{\mathrm{T}}$ using lactate as electron donor in sulphate-free medium. Strain RT2 ${ }^{\mathrm{T}}$ was able to ferment pyruvate $(20 \mathrm{mM})$, but not lactate $(20 \mathrm{mM})$ or fumarate $(20 \mathrm{mM})$. Strain RT2 ${ }^{\mathrm{T}}$ did not grow aerobically.

The $\mathrm{G}+\mathrm{C}$ content of genomic DNA was determined at the Identification Service of the DSMZ (Deutsche Sammlung von Mikroorganismen und Zellkulturen, Braunschweig, Germany), according to their recommended protocol.

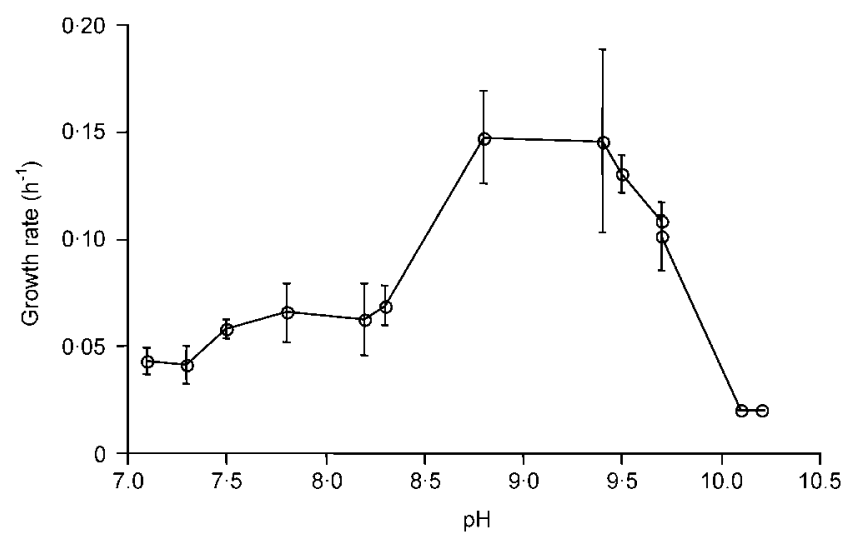

Fig. 1. Effect of $\mathrm{pH}$ on the specific growth rate of strain $\mathrm{RT}^{\top}$ (representative data). Means \pm SD of three independent determinations are shown.
DNA of strain $\mathrm{RT} 22^{\mathrm{T}}$ was extracted and the $16 \mathrm{~S}$ rRNA gene was retrieved as described previously (Abildgaard et al., 2004). Approximately $1900 \mathrm{bp}$ of the $d s r A B$ gene sequence (genes encoding the $\alpha$ - and $\beta$-subunits of the dissimilatory sulphite reductase) was amplified by PCR from a DNA extract of strain $\mathrm{RT}^{\mathrm{T}}$ as well as being cloned as described previously (Mogensen et al., 2005). Plasmid inserts were sequenced as described below using the primers vectorF and vectorR (Thomsen et al., 2001) and a custom-designed internal $d s r A B$ gene sequencing primer ( 5 '-TCGACATCATGAAGGAAGTCG-3') for the sequencing reactions. In addition the apsA gene (encoding the adenosine-5'-phosphosulphate reductase $\alpha$-subunit) was amplified by PCR using the primers APS7-F and APS8-R (Friedrich, 2002), the HotStarTaq system (Qiagen) and thermal cycling according to Friedrich (2002). PCR products of the expected size ( $900 \mathrm{bp}$ ) were cut out of agarose gels, purified and sequenced directly as described below using the primers APS7-F and APS8-R for the sequencing reactions. All PCR products and plasmids were sequenced using an ABI 3100 DNA sequencer (Applied Biosystems) with a DYEnamic ET Terminator sequencing kit (Amersham Biosciences). Sequences of the respective genes were aligned and compiled as described previously (Mogensen et al., 2005). Phylogenetic trees based on 16S rRNA gene sequence datasets were constructed using the distance-matrix, maximumparsimony and maximum-likelihood algorithms of the ARB program package (Ludwig et al., 2004). A custom-made $50 \%$ conservation filter for $16 \mathrm{~S}$ rRNA gene sequences from 41 recognized Desulfovibrio species was used to select sequence positions for the analyses. Topologies that could not be resolved unambiguously using the various analyses are shown as multifurcations in the 16S rRNA gene-based phylogenetic consensus tree displayed in Fig. 2, as recommended by Ludwig et al. (1998). To simplify the tree, some species not closely related to strain $\mathrm{RT} 2^{\mathrm{T}}$ were later removed. DsrAB and ApsA amino acid sequence-based phylogenetic trees were inferred using the distance-matrix (FITCH analysis performed according to Friedrich, 2002), maximumparsimony and maximum-likelihood (with the JTT amino acid replacement model) algorithms for analysis of amino acid sequence data of the ARB program package. Datasets (deduced from $d s r A B$ and apsA gene sequences) including 540 and 241 unambiguously aligned DsrAB and ApsA amino acid sequence positions, respectively, were analysed. Short DsrAB and ApsA amino acid sequences were added to the trees without changing the overall tree topology using the PARSIMONY_INTERAKTIV tool of the ARB program package. Distance matrix-based bootstrap analyses of DsrAB and ApsA amino acid sequence datasets were performed in PAUP $^{\star}$ version 4.0b10 (Swofford, 2003). Consensus trees were constructed as described above.

Phylogenetic analyses based on 16S rRNA gene sequence datasets clearly showed that strain $\mathrm{RT}^{\mathrm{T}}$ belongs to the genus Desulfovibrio within the Deltaproteobacteria (Fig. 2). A similar affiliation was confirmed by DsrAB and ApsA amino acid sequence analyses (see Supplementary Fig. S2 


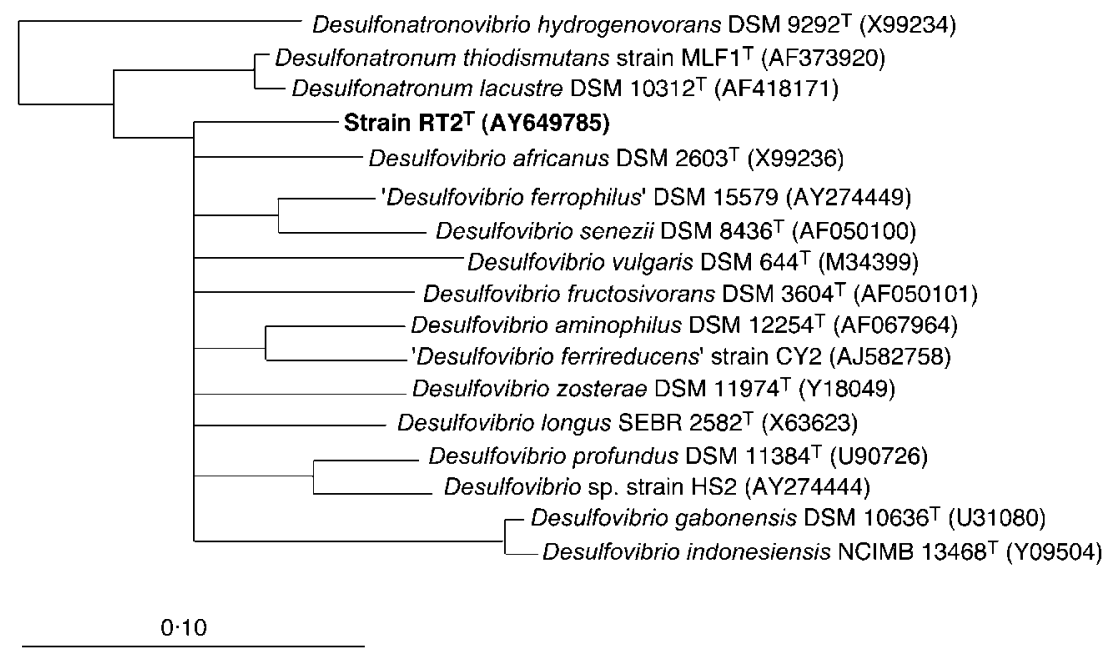

Fig. 2. Phylogenetic consensus tree showing the affiliation of the 16S rRNA gene sequence of strain $\mathrm{RT}^{\top}$ to selected reference sequences from members of the class Deltaproteobacteria. The tree was inferred from neighbour-joining, maximum-parsimony and maximum-likelihood analyses of datasets comprised of almost complete 16S rRNA gene sequences. Topologies that could not be resolved unambiguously are shown as multifurcations. GenBank accession numbers are given in parentheses. Bar, 10 nucleotide substitutions per 100 nucleotides, as estimated by maximum-likelihood analysis.

in IJSEM Online). Pairwise alignment of $16 \mathrm{~S}$ rRNA gene sequences showed that strain RT2 ${ }^{\mathrm{T}}$ clearly differs phylogenetically from other Desulfovibrio species. Thus, strain $\mathrm{RT}^{\mathrm{T}}$ shared $90 \cdot 7$ and $90 \cdot 1 \% 16 \mathrm{~S}$ rRNA gene sequence similarity with its closest relatives, Desulfovibrio africanus and Desulfovibrio aminophilus, respectively, over an alignment of 1210 sequence positions. Desulfovibrio africanus is different from strain $\mathrm{RT} 2^{\mathrm{T}}$ in motility (has lophotrichous flagella) and shape (sigmoid instead of vibrio-shaped) and also has a narrower temperature tolerance (Table 1). The $\mathrm{pH}$ range of Desulfovibrio africanus is not known and thus cannot be compared. Desulfovibrio aminophilus and strain $\mathrm{RT}^{\mathrm{T}}$ are both vibrio-shaped with polar flagella. However, they differ markedly in optimum and cardinal values of $\mathrm{pH}$, temperature and $\mathrm{NaCl}$ (Table 1). Furthermore, the range of electron donors utilized by Desulfovibrio aminophilus is larger than that for strain RT2 ${ }^{\mathrm{T}}$ (Table 1; Baena et al., 1998).

As mentioned above, incubation of strain $\mathrm{RT} 2^{\mathrm{T}}$ with mild steel coupons $\left(\mathrm{Fe}^{0}\right)$ as a potential electron donor resulted in insignificant sulphate-reducing activities. However, whether strain $\mathrm{RT} 2{ }^{\mathrm{T}}$ is involved in MIC, which has been observed in

Table 1. Comparison of selected characteristics of strain $R T 2^{\top}$ and its phylogenetically closest relatives

Strains: 1, Desulfovibrio africanus DSM $2603^{\mathrm{T}}$ (data from Postgate, 1984); 2, Desulfovibrio aminophilus DSM $12254^{\mathrm{T}}$ (Baena et al., 1998); 3, RT2 ${ }^{\mathrm{T}}$. Optimum values are shown in parentheses. +, Positive; -, negative; NA, not applicable; ND, not determined. All three species are capable of using lactate, pyruvate and hydrogen/acetate as electron donors.

\begin{tabular}{|c|c|c|c|}
\hline Characteristic & 1 & 2 & 3 \\
\hline Cell shape & Sigmoid & Vibrio & Vibrio \\
\hline Flagellation & Lophotrichous & Single polar & Single polar \\
\hline Size $(\mu \mathrm{m})$ & $0 \cdot 5 \times 5 \cdot 0-10 \cdot 0$ & $0 \cdot 2 \times 3 \cdot 0-4 \cdot 0$ & $0 \cdot 5-0 \cdot 8 \times 1 \cdot 4-1 \cdot 9$ \\
\hline $\mathrm{pH}$ range & ND & $6 \cdot 7-8 \cdot 0(7 \cdot 5)$ & $6 \cdot 9-9 \cdot 9(9 \cdot 0-9 \cdot 4)$ \\
\hline $\mathrm{NaCl}$ maximum $(\%)$ & ND & $2(0 \cdot 05-0 \cdot 75)$ & $0 \cdot 7(0 \cdot 13)$ \\
\hline Temperature range $\left({ }^{\circ} \mathrm{C}\right)$ & $28-40(34-37)$ & 25-40 (35) & $16-47(43)$ \\
\hline DNA G + C content $(\mathrm{mol} \%)$ & $60 \cdot 2$ & 66 & $64 \cdot 7$ \\
\hline $\begin{array}{l}\text { 16S rRNA gene sequence } \\
\text { similarity to } \mathrm{RT}^{\mathrm{T}}(\%)\end{array}$ & $90 \cdot 7$ & $90 \cdot 1$ & NA \\
\hline \multicolumn{4}{|l|}{ Electron donors (with $\left.\mathrm{SO}_{4}^{2-}\right)^{\star}$ : } \\
\hline Formate & ND & + & + \\
\hline Malate & + & ND & - \\
\hline Ethanol & + & + & - \\
\hline Fermentative growth on pyruvate & ND & + & + \\
\hline
\end{tabular}

${ }^{\star}$ Desulfovibrio aminophilus utilizes a broad spectrum of electron donors; only those tested for all three strains are included for comparison. 
the district heating system from which it was isolated, remains to be investigated. The optimum growth temperature and $\mathrm{pH}$ value determined in vitro for strain $\mathrm{RT}_{2}{ }^{\mathrm{T}}$ corresponded well with the physico-chemical conditions prevailing in the bulk water of the district heating system, i.e. $40^{\circ} \mathrm{C}$ and $\mathrm{pH} 9 \cdot 5-10$. Thus, strain $\mathrm{RT}^{\mathrm{T}}$ appears to be well-adapted to thrive in such heating systems. This emphasizes the importance of maintaining a low availability of organic substrates in district heating systems, as an SRB such as strain $\mathrm{RT}^{\mathrm{T}}$ would probably otherwise proliferate, resulting in a concomitant production of corrosive hydrogen sulphide.

On the basis of the physiological and molecular properties of strain $\mathrm{RT} 2^{\mathrm{T}}$ and its closest relatives, we propose that strain $\mathrm{RT}^{\mathrm{T}}$ should be recognized as representing a novel species of the genus Desulfovibrio. The name Desulfovibrio alkalitolerans sp. nov. is proposed for this organism, in accordance with its ability to grow under alkaline conditions.

\section{Description of Desulfovibrio alkalitolerans sp. nov.}

Desulfovibrio alkalitolerans [al.ka.li.to'le.rans. Arabic n. alkali (al-qaliy), the ashes of saltwort; L. pres. part. tolerans tolerating; N.L. part. adj. alkalitolerans alkali-tolerating].

Motile, vibrio-shaped cells with a single polar flagellum and $0.5-0.8 \times 1.4-1.9 \mu \mathrm{m}$ in size. Non-spore-forming. Alkalitolerant: $\mathrm{pH}$ range $6 \cdot 9-9 \cdot 9$, with optimum growth occurring at $9 \cdot 0-9 \cdot 4$. NaCl range for growth is $0 \cdot 085$ $0 \cdot 7 \%(\mathrm{w} / \mathrm{v})$; optimum growth occurs at $0 \cdot 13 \%$. Mesophilic: temperature range for growth is $16-47^{\circ} \mathrm{C}$; optimum growth at $43^{\circ} \mathrm{C}$. Anaerobic, but tolerates short exposure to oxygen. Growth occurs with lactate, pyruvate, formate and hydrogen/acetate as electron donors and sulphate, sulphite and thiosulphate as electron acceptors. Fermentative growth occurs on pyruvate. Yeast extract is required for growth. The genomic $\mathrm{G}+\mathrm{C}$ content of the type strain is $64 \cdot 7 \mathrm{~mol} \%$.

The type strain, RT2 ${ }^{\mathrm{T}}\left(=\mathrm{DSM} 16529^{\mathrm{T}}=\mathrm{JCM} 12612^{\mathrm{T}}\right.$ ), was isolated from mild steel coupons from a reactor connected to the return line of the Skanderborg district heating plant (Jutland, Denmark).

\section{Acknowledgements}

This study was financially supported by the Danish Technical Research Council under the framework programme 'Activity and Diversity in Complex Microbial Systems'. We thank Tove Wiegers, Pernille Thykier and Britta Poulsen for technical assistance.

\section{References}

Abildgaard, L., Ramsing, N. B. \& Finster, K. (2004). Characterization of the marine propionate-degrading, sulfate-reducing bacterium Desulfofaba fastidiosa sp. nov. and reclassification of Desulfomusa hansenii as Desulfofaba hansenii comb. nov. Int J Syst Evol Microbiol 54, 393-399.
Baena, S., Fardeau, M. L., Labat, M., Ollivier, B., Garcia, J. L. \& Patel, B. K. (1998). Desulfovibrio aminophilus sp. nov., a novel amino acid degrading and sulphate reducing bacterium from an anaerobic dairy wastewater lagoon. Syst Appl Microbiol 21, 498-504.

Cline, J. D. (1969). Spectrophotometric determination of hydrogen sulfide in natural waters. Limnol Oceanogr 14, 454-458.

Dinh, H. T., Kuever, J., Mussmann, M., Hassel, A. W., Stratmann, M. \& Widdel, F. (2004). Iron corrosion by novel anaerobic microorganisms. Nature 427, 829-832.

Elsgaard, L., Isaksen, M. F., Jørgensen, B. B., Alayse, A.-M. \& Jannasch, H. W. (1994). Microbial sulphate reduction in deep-sea sediments at the Guaymas Basin hydrothermal vent area: influence of temperature and substrates. Geochim Cosmochim Acta 58, 3335-3343.

Fossing, H. \& Jørgensen, B. B. (1989). Measurement of bacterial sulphate reduction in sediments: evaluation of a single-step chromium reduction method. Biogeochemistry 8, 205-222.

Friedrich, M. W. (2002). Phylogenetic analysis reveals multiple lateral transfers of adenosine-5'-phosphosulfate reductase genes among sulfate-reducing microorganisms. J Bacteriol 184, 278-289.

Goeres, D. M., Nielsen, P. H., Smidt, H. D. \& Frølund, B. (1998). The effect of alkaline $\mathrm{pH}$ conditions on a sulphate reducing consortium from a Danish district heating plant. Biofouling 12, 273-286.

Hamilton, W. A. (1985). Sulphate-reducing bacteria and anaerobic corrosion. Annu Rev Microbiol 39, 195-217.

Hamilton, W. A. (1998). Bioenergetics of sulphate-reducing bacteria in relation to their environmental impact. Biodegradation 9, 202-212.

Hamilton, W. A. (2003). Microbially influenced corrosion as a model system for the study of metal microbe interactions: a unifying electron transfer hypothesis. Biofouling 19, 65-76.

Hungate, R. E. (1976). A roll tube method for cultivation of strict anaerobes. Methods Microbiol 3B, 117-132.

Ingvorsen, K. \& Jørgensen, B. B. (1984). Kinetics of sulfate uptake by freshwater and marine species of Desulfovibrio. Arch Microbiol 139, 61-66.

Kjellerup, B. V., Olesen, B. H., Nielsen, J. L., Frølund, B., Ødum, S. \& Nielsen, P. H. (2003). Monitoring and characterization of bacteria in corroding district heating systems using fluorescence in situ hybridisation and microautoradiography. Water Sci Technol 47, 117-122.

Kjellerup, B. V., Thomsen, T. R., Nielsen, J. L., Olesen, B. H., Frølund, B. \& Nielsen, P. H. (2005). Microbial diversity in biofilms from corroding heating systems. Biofouling 21, 19-29.

Lovley, D. (2000). Dissimilatory Fe(III)- and Mn(IV)-reducing prokaryotes. In The Prokaryotes: an Evolving Electronic Resource for the Microbiological Community, 3rd edn, release 3.4, 12 January 2000. Edited by M. Dworkin, S. Falkow, E. Rosenberg, K.-H. Schleifer \& E. Stackebrandt. New York: Springer. http://141.150.157.117:8080/ prokPUB/index.htm

Ludwig, W., Strunk, O., Klugbauer, S., Klugbauer, N., Weizenegger, M., Neumaier, J., Bachleitner, M. \& Schleifer, K. H. (1998). Bacterial phylogeny based on comparative sequence analysis. Electrophoresis 19, 554-568.

Ludwig, W., Strunk, O., Westram, R. \& 29 other authors (2004). ARB: a software environment for sequence data. Nucleic Acids Res 32, 1363-1371.

Mogensen, G. L., Kjeldsen, K. U. \& Ingvorsen, K. (2005). Desulfovibrio aerotolerans sp. nov., an oxygen tolerant sulfate-reducing bacterium isolated from activated sludge. Anaerobe 11, 339-349.

Pak, K.-R., Lee, H.-J., Lee, H. K., Kim, Y.-K., Oh, Y.-S. \& Choi, S.-C. (2003). Involvement of organic acid during corrosion of iron coupon by Desulfovibrio desulfuricans. J Microbiol Biotechnol 13, 937-941. 
Pankhania, I. P. (1988). Hydrogen metabolism in sulphate-reducing bacteria and its role in anaerobic corrosion. Biofouling 1, 27-47.

Peck, H. D., Jr (1993). Bioenergetic strategies of the sulfate-reducing bacteria. In The Sulfate-Reducing Bacteria: Contemporary Perspectives, pp. 41-76. Edited by J. M. Odom \& R. Singleton, Jr. New York: Springer.

Pikuta, E. V., Zhilina, T. N., Zarvarzin, G. A., Kostrikina, N. A., Osipov, G. A. \& Rainey, F. A. (1998). Desulfonatronum lacustre sp. nov. a new alkaliphilic sulfate-reducing bacterium utilizing ethanol. Mikrobiologiia 67, 123-131 (in Russian).

Pikuta, E., Lysenko, A., Suzina, N., Osipov, G., Kuznetsov, B., Tourova, T., Akimenko, V. \& Laurinavichius, K. (2000). Desulfotomaculum alkaliphilum sp. nov., a new alkaliphilic, moderately thermophilic, sulfate-reducing bacterium. Int J Syst Evol Microbiol 50, 25-33.

Pikuta, E. V., Hoover, R. B., Bej, A. K., Marsic, D., Whitman, W. B., Cleland, D. \& Krader, P. (2003). Desulfonatronum thiodismutans sp. nov., a novel alkaliphilic, sulfate-reducing bacterium capable of lithoautotrophic growth. Int J Syst Evol Microbiol 53, 1327-1332.

Postgate, J. R. (1984). Genus Desulfovibrio Kluyver and van Niel 1936, 397 ${ }^{\mathrm{AL}}$. In Bergey's Manual of Systematic Bacteriology, vol. 1, pp. 666-672. Edited by N. R. Krieg \& J. G. Holt. Baltimore: William \& Wilkins.
Rao, T. S., Sairam, T. N., Viswanathan, B. \& Nair, K. V. K. (2000). Carbon steel corrosion by iron oxidizing and sulphate-reducing bacteria in a freshwater cooling system. Corros Sci 42, 1417-1431.

Swofford, D. L. (2003). PAUP* - Phylogenetic Analysis Using Parsimony ( ${ }^{*}$ and other methods), version 4. Sunderland, MA: Sinauer Associates.

Thomsen, T. R., Finster, K. \& Ramsing, N. B. (2001). Biogeochemical and molecular signatures of anaerobic methane oxidation in a marine sediment. Appl Environ Microbiol 67, 1646-1656.

Widdel, F. \& Bak, F. (1992). Gram-negative mesophilic sulfatereducing bacteria. In The Prokaryotes, 2nd edn, pp. 3352-3378. Edited by A. Balows, H. G. Trüper, M. Dworkin, W. Harder \& K.-H. Schleifer. New York: Springer.

Zhilina, T. N., Zavarzin, G. A., Rainey, F. A., Pikuta, E. N., Osipov, G. A. \& Kostrikina, N. A. (1997). Desulfonatronovibrio hydrogenovorans gen. nov., sp. nov., an alkaliphilic, sulfate-reducing bacterium. Int J Syst Bacteriol 47, 144-149.

Zhilina, T. N., Zavarzina, D. G., Kuever, J., Lysenko, A. M. \& Zavarzin, G. A. (2005). Desulfonatronum cooperativum sp. nov., a novel hydrogenotrophic, alkaliphilic, sulfate-reducing bacterium, from a syntrophic culture growing on acetate. Int J Syst Evol Microbiol 55, 1001-1006. 